\title{
Pemberdayaan Masyarakat Kota di Wilayah RW VI Kelurahan Jatimulyo Malang Melalui Model Budidaya Sayur Organik
}

\author{
Indiyah Murwani $^{1}$, Siti Muslikah ${ }^{2}$, Siti Asmaniyah Mardiyani ${ }^{3}$ \\ 1,2,3 Universitas Islam Malang \\ email : Indiyahmur@unisma.ac.id ${ }^{1}$, sitimuslikah@unisma.ac.id², asmaniyah@unisma.ac.id³
}

\begin{abstract}
This activity aims to increase housewives' productivity in the Brantas river basin, Merjosari Malang, through organic vegetable cultivation. The method is done by training and practicing how to manage organic waste into compost, which can be used to grow vegetables in narrow areas using the verticulture system. The data obtained show that the community's awareness not to throw garbage in the river is relatively high, namely $100 \%$. Only $10 \%$ of residents throw garbage in their yards because garbage officers always pick up trash. The mothers have separated their waste, starting from the kitchen and organic waste. The number of mothers who sort organic waste and use it as compost is still relatively low, at 35\%. Therefore, the team's activities focused on providing counseling related to household organic waste as compost raw material, which could be used as a growing medium for vertical vegetable gardens. Extension activities were carried out two times, namely providing material and practice. The primary informations given were organic waste as compost and the method of verticulture cultivation of vegetables.
\end{abstract}

Keywords: housewives, river basin, organic, waste.

\begin{abstract}
Abstrak
Ibu-ibu yang tinggal di wilayah RW VI sebagian tidak bekerja sehingga masih memiliki waktu untuk melakukan kegiatan produktif, dengan cara melakukan budidaya sayur organik. Metode yang dilakukan dengan melatih dan praktek cara mengelola sampah organik menjadi kompos yang dapat dimanfaatkan sebagai media tanam sayuran. Sempitnya lahan bertanam diatasi dengan sistem tanam vertikultur. Data yang diperoleh bahwa kesadaran masyarakat untuk tidak membuang sampah di sungai cukup tinggi yaitu sebesar $100 \%$, warga yang membuang sampah di pekarangan sendiri hanya $10 \%$, karena ada petugas sampah yang selalu mengambil sampah. Dari hasil pengamatan di lapang bahwa ibu-ibu sudah melakukan pemilahan sampah mulai dari dapur, dengan memilih sampah anorganik yang dijual ke tukang rombeng, sebesar $75 \%$. Ibu-ibu yang melakukan pemilahan sampah organik dan memanfaatkan sebagai bahan kompos masih cukup rendah, yaitu sebesar $35 \%$. Oleh karena itu tim terfokus melakukan penyuluhan terkait pemanfaatan sampah organik rumah tangga sebagai bahan baku kompos yang dapat dipergunakan sebagai media tumbuh bagi kebun sayur vertikultur. Kegiatan penyuluhan dilakukan 2 kali yakni pemberian materi dan praktek. Materi utama yang diberikan adalah pemanfataan sampah organik sebagai kompos dan praktek budidaya sayuran secara vertikultur.
\end{abstract}

Kata Kunci: ibu rumah tangga, bantaran sungai, organik, sampah.

Artikel diterima : 31 Januari $2021 \quad$ direvisi : 19 Februari 2021

disetujui : 01 April 2020 


\section{Pendahuluan}

Daerah kota Malang bagian utara dan barat merupakan wilayah yang dilalui oleh Aliran Sungai Brantas. DAS Brantas mempunyai manfaat yang sangat besar, akan tetapi apabila tidak dijaga kebersihannya dengan baik justru akan mendatangkan musibah bagi penduduk sekitarnya. Sebagian perempuan yang tinggal di kawasan ini tidak bekerja atau bekerja serabutan sehingga masih memiliki waktu luang untuk melakukan berbagai kegiatan produktif. Oleh karena itu kegiatan untuk meningkatkan keterampilan masyarakat dalam melakukan budidaya sayur organik. Model teknologi ini perlu disosialisasikan kepada masyarakat di daerah bantaran sungai Brantas dalam rangka peningkatan kemandirian pangan dan ekonomi masyarakat. Jika program ini dapat berkesinambungan maka akan menghasilkan pendapatan yang akan meningkatkan perekonomian ekonomi keluarga.

Jumlah penduduk Indonesia mengalami peningkatan yang sangat pesat setiap tahun, sehingga luas lahan yang tersedia dan dapat diolah untuk areal pertanian juga semakin terbatas. Bahkan tidak sedikit juga lahan pertanian berubah fungsinya menjadi area industri, perumahan dan gedung perkantoran. Ini menjadi kesempatan untuk berkembang vertikultur intensif. Sistem vertikultur sangat cocok untuk diterapkan bagi petani atau orang yang memiliki lahan sempit, tetapi menginginkan hasil tanaman yang banyak (Munthe et al., 2018).

Pertanian perkotaan dapat meningkatkan pendapatan masyarakat dengan cara memproduksi bahan pangan sendiri untuk dikonsumsi. Selain itu juga bermanfaat untuk keindahan kota, rekreasi dan relaksasi bagi masyarakat. Kegiatan pertanian perkotaan secara langsung dan tidak langsung berdampak terhadap kesejahteraan masyarakat itu sendiri (Sastro, 2013).

Pertanian perkotaan di kota Surabaya bertujuan mengentaskan kemiskinan. Ge- rakan pertanian perkotaan untuk meningkatkan kemandirian masyarakat untuk menjaga pertahanan pangan khususnya ditingkat rumah tangga (Santoso \& Widya, 2014).

Pertanian perkotaan yang dilaku-kan komunitas Bandung Berkebun melalui proses perencanaan, diantaranya kemampuan masyarakat dalam berkebun, dan pemilihan lokasi yang dapat digunakan untuk berkebun (Puriandi \& Indrajati, 2013). Lokasi, luas lahan, pola tanam, sarana produksi, ketersediaan dan penggunaan sumber daya dan kesejahteraan rumah tangga sebagai karakterisasi Urban and Periurban Agriculture (Abdalla, 2012).

Pertanian organik modern didefinisikan sebagai sistem budidaya pertanian yang mengandalkan bahan-bahan alami tanpa menggunakan bahan kimia sintetis. Pengelolaan pertanian organik didasarkan pada prinsip kesehatan, ekologi, keadilan, dan perlindungan. Keberlanjutan pertanian organik, tidak dapat dipisahkan dengan dimensi ekonomi, selain dimensi lingkungan dan dimensi sosial. Pertanian organik juga pemanfaatan sumber-sumber daya alam secara berkelanjutan, produksi makanan sehat dan menghemat energi (Yanti, 2005).

Pertanian organik semakin diminati masyarakat khususnya yang sangat memperhatikan kualitas kesehatan, baik kesehatan manusia maupun lingkungan. Produk pertanian organik sangat baik untuk memperbaiki kesehatan manusia dan lingkungan karena dihasilkan melalui proses produksi yang berwawasan lingkungan. Kesadaran masyarakat tentang pangan sehat telah menyebabkan permintaan produk pertanian organik naik sekitar 20$30 \%$ per tahun (BPS, 2010).

Media tanam untuk pertanian organik dapat menggunakan kompos. Bahan untuk pembuatan kompos cukup sederhana, dapat dibuat dari limbah rumah tangga, limbah perkebunan, limbah pertanian dan limbah peternakan. Teknik pembuatan kompos dapat dengan cara teknik berlapis dan teknik campur atau mix. Waktu yang 
diperlukan dalam pengomposan adalah antara tiga minggu sampai dua bulan, tergantung bahan yang digunakan. Pupuk organik dilihat dari segi harga tidak perlu mengeluarkan biaya yang mahal karena bisa menyesuaikan limbah yang ada (Nisa, 2016).

Pertanian berkelanjutan (sustainable agriculture) dengan memanfaatkan sumberdaya yang dapat diperbaharui (renewable resources) dan sumberdaya tidak dapat diperbaharui (unrenewable resources) untuk proses produksi pertanian dengan mengurangi dampak negatif terhadap lingkungan seminimal mungkin. Keberlanjutan yang dimaksud yang terdiri dari penggunaan sumberdaya, kualitas dan kuantitas produksi, serta lingkungannya. Proses pertanian yang berkelanjutan akan mengarah pada penggunaan produk hayati yang ramah lingkungan (Untung, 1997).

Lahan yang sempit bukan menjadi kendala untuk membuat lingkungan menjadi hijau dan indah. Salah satu diantaranya adalah bertanam secara vertikultur. Vertikultur adalah sistem budidaya yang dilakukan secara bertingkat, baik di luar ruangan maupun di dalam ruangan. Cara bertanam dapat menggunakan rak bertingkat, menggantung atau bersusun dengan beberapa wadah. Teknik bertanam ini bermula dari kegiatan pertanian di luar ruangan di Belanda (Liferdi \& Saparinto, 2016).

Bertanam secara vertikultur mempunyai beberapa keuntungan diantaranya (1) Efisiensi penggunaan lahan karena dibuat secara bersusun, (2) portable, ditanam dengan wadah pot/polybag/ botol/ kaleng, tanaman mudah dipindahkan, (3) mengurangi penyiangan, karena penanaman secara vertikal mengurangi tumbuhnya gulma, (4) penghematan pupuk, karena dalam wadah yang terbatas sehingga tidak mudah tercuci oleh hujan, (5) penghematan pestisida, (6) jika diberi atap dapat mencegah kerusakan karena hujan, (7) jika ditanam di rumah kaca dapat mengurangi penyiraman, (8) mempunyai segi keindahan dan estetika yang baik, apabila ditata dengan baik dan (9) mempermudah perawatan, karena tanaman berada di satu lokasi. (Liferdi \& Saparinto, 2016).

Bentuk dan model vertikultur. Bentuk dan model tergantung kreatifitas dan kemampuan dalam menggunakan bahan yang ada. Secara umum dan yang sering dujumpai adalah bentuk persegi panjang, segitiga, pyramid, bentuk anak tangga dengan berbagai undakan, bentuk rak yang ditempelkan pada dinding. Wadah yang bisa digunakan adalah pot, kaleng bekas cat, botol bekas air minum atau yang lain, asalkan ringan. Agar diperoleh hasil dan manfaat yang baik, desain dan penanaman harus dilakukan dengan berbagai pertimbangan (1) penompang verticultur harus kuat karna menahan beban diatasnya, (2) bila menggunakan sistem portable perangkat vertikultur harus mudah dipindahkan, (3) bila beroreantasi komersial perlu adanya aspek ekonominya agar biaya produksi tertutup dengan hasil penjualan tanaman, (4) tanaman yang akan ditanam sebaiknya disesuaikan dengan kebutuhan dan memiliki nilai ekonomis tinggi, berumur pendek, berakar pendek, jenis tanamanan sayuran yang dibudidayakan secara vertikultur diantaranya selada, pakcoy, bayam, kangkung, caysim, kathuk, kemangi, mentimun, tomat, bawang merah dan cabai (Liferdi \& Saparinto, 2016).

Bertanam sayur dapat dilakukan di pot. Penggunaan pot sebagai media tanam lebih mudah dipindahkan (Rosy, 2017). Bertanam sayur di pot ada keuntungan diantaranya suasana rumah menjadi lebih asri dan segar, karena pot dapat ditata di teras rumah secara rapi. Bertanam di pot benih dapat ditanam langsung tanpa persemaian contohnya bayam dan kangkung, tapi ada juga tanaman yang disemaikan terlebih dahulu lalu dipindah ke dalam pot penanaman. Benih yang harus disemaikan adalah terong, tomat dan cabe (Alex, 2016).

Tanaman sayur dapat tumbuh dengan baik jika faktor lingkungan mendukung. Kesesuaian media tumbuh dan 
iklim penting untuk diketahui karena sangat menentukan tanaman dapat tumbuh dengan baik atau tidak. Syarat tumbuh meliputi syarat teknis dan non teknis. Syarat teknis adalah (1) jenis dan varietas tanaman, (2) media, (3) pemupukan, (4) pengolahan air, (5) pengendalian hama, penyakit dan gulma, (6) pola penanam. Syarat non teknis adalah (1) lingkungan, (2) iklim, (3) pasar, (4) tenaga kerja, (5) modal (Liferdi \& Saparinto, 2016).

\section{Permasalahan Mitra}

Mitra di wilayah RW VI Jatimulyo berada di wilayah DAS Brantas yang saat ini masih memiliki kesadaran yang terbatas tentang pengelolaan lingkungan sehat yang menunjang kehidupan mereka. Meskipun telah ada tempat sampah untuk menampung sampah keluarga namun belum ada pemanfaatan sampah organik menjadi kompos. Masyarakat juga belum memiliki kebun-kebun vertikultur organik yang bisa dimanfaatkan untuk meningkatkan akses keluarga terhadap sumber pangan nabati bergizi tinggi.

\section{Solusi dan target luaran}

Metode pengabdian masyarakat yang dilakukan adalah cara melatih dan praktek pada ibu ibu di wilayah RW VI cara mengelola sampah organik menjadi kompos. Kompos yang dihasilkan dapat dimanfaatkan sebagai media tanam sayuran. Sempitnya lahan bertanam maka diatasi dengan sistem tanam vertikultur yaitu bertanam secara bertingkat. Dengan sistem tanam vertikultur atau bertingkat dapat menanam tanaman yang lebih banyak pada luasan terbatas.

Sayuran organik yang dihasilkan dapat dimanfaatkan untuk memenuhi gizi keluarga. Pengelolaan tanaman sayuran yang dihasilkan jika berlebih maka dapat dijual untuk meningkatkan pendapatan keluarga. Agar sayuran mempunyai nilai tinggi, maka perlu dilakukan pengolahan pasca panen yang benar.

\section{Target Luaran}

1. Masyarakat mitra paham dan terampil dalam mengadopsi teknologi pengolahan sampah sehingga nantinya dapat dijadikan usaha produktif .

2. Terciptanya budaya memanfaatkan sampah lingkungan sekitar meski sempit sebagai lahan pertanian dengan model vertikultur yang menghemat tempat. Budidaya sayur mayur diharapkan dapat dilakukan oleh masyarakat secara berkesinambungan untuk mengatasi permasalahan kekurangan gizi dan keterbatasan kemampuan ekonomi.

\section{Metode Pelaksanaan}

\section{Pelaksanaan}

Solusi yang ditawarkan dalam rangka memecahkan permasalahan yang ada di RW VI Jatimulyo Malang dengan cara memasyarakatkan teknologi pengolahan sampah sampai pemanfaatannya guna meningkatkan nilai tambah melalui lima tahap karena mengingat bahwa kemampuan daya pikir serta daya tangkap yang dimiliki masyarakat berbeda-beda. Adapun metode yang dilakukan melalui tahapantahapan berikut :

1. Tahap Pengenalan

Pada tahap ini mulai dilakukan perkenalan pada khalayak sasaran terutama masyarakat yang menjadi sasaran pengabdian, bagaimana minat dari khalayak sasaran kita lihat dan akhirnya kita tentukan jadwal dari pelaksanaan kegiatan.

2. Tahap Pelaksanaan

Pada tahap ini adalah tahap melaksanakan pemasyarakatan teknologi pengolahan sampah sesuai dengan penjadwalan yang telah dibuat bersamasama antara tim dengan khalayak sasaran. Pelaksanaan dilakukan melalui program penyuluhan, yaitu dengan menyampaikan cara pembuatan pupuk organik dari sampah rumah tangga dan cara penanaman secara vertikultur. Kegiatan ini memiliki keterkaitan yang erat dengan Dinas Ketahanan Pangan, 
Pemerintah setempat (Kelurahan) karena keberhasilan program ini dapat mengantisipasi pemenuhan kebutuhan sayuran untuk meningkatkan nutrisi pada masyarakat di bantaran sungai Brantas.

3. Tahap evaluasi program. Evaluasi dilakukan untuk melihat keberhasilan pelaksanaan program. Evaluasi direncanakan dilakukan pada pertengahan program dan akhir program. Evaluasi pertengahan program dimaksudkan untuk mengetahui pemahaman mengenai arti penting budidaya sayur organik. Evaluasi pada akhir kegiatan dilakukan untuk melihat respon khalayak sasaran terhadap inovasi budidaya sayur organik yang dikembangkan. Evaluasi dilakukan dengan cara wawancara dan penyebaran kuesioner.

\section{Hasil dan Pembahasan}

Berdasarkan hasil diskusi sebelum penyuluhan, sebagian besar peserta pengabdian belum pernah mendengar istilah budidaya secara vertikultur sementara beberapa sudah mendengar tentang hidroponik tetapi tidak mengetahui cara pengaplikasiannya. Dalam materi penyuluhan disampaikan tentang budidaya secara vertikultur. Beberapa model budidaya vertikultur dapat diletakkan di halaman rumah, tepi jalan dan tembok.

Dalam penyuluhan juga dijelaskan tentang manfaat dari pupuk kompos. $\mathrm{Pu}-$ puk kompos dapat meningkatkan kembali kesuburan tanah, dan mengembalikan nutrisi tanah yang hilang akibat dari aktivitas panen maupun yang terbawa oleh air (Nisa, 2016).

Kegiatan yang dilaksanakan meliputi perkenalan dengan pengurus RW dengan dan penyuluhan dengan materi cara pengelolaan sampah rumah tangga untuk dibuat kompos untuk bertanam sayur secara vertikultur. Pada saat penyuluhan diserahkan rak vertikultur dan juga dilakukan pembagian modul dengan judul "Urban Farming Daerah Aliran Sungai”.

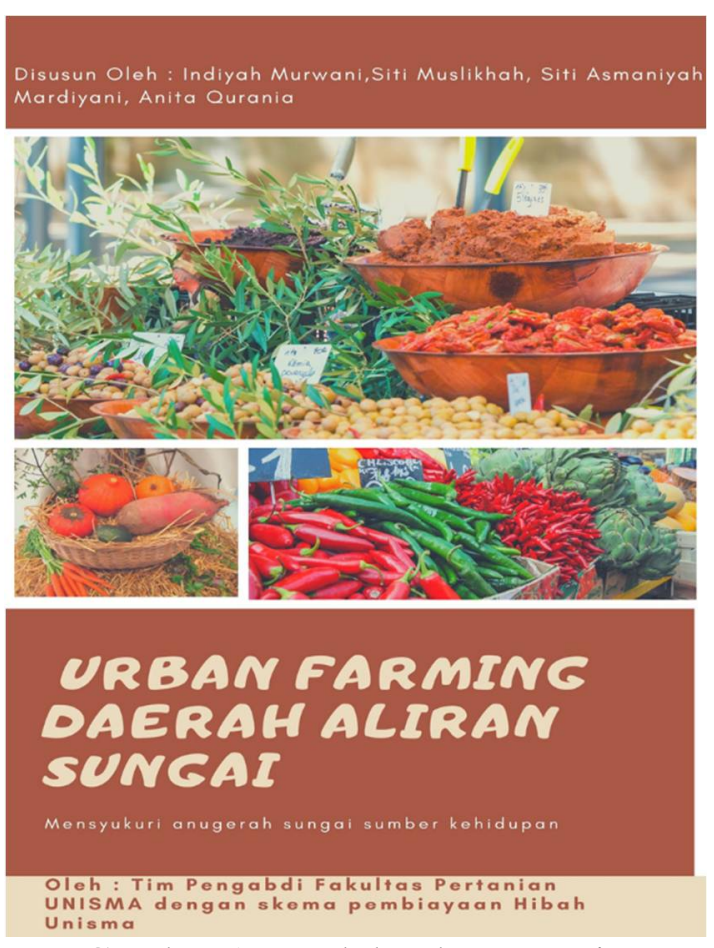

Gambar 1: Modul Urban Farming

Modul diantaranya berisi cara pengelolaan sampah. Sampah terbukti dapat merugikan, tetapi ada sisi manfaatnya. Hal ini karena selain dapat mendatangkan bencana bagi masyarakat, sampah juga dapat diubah menjadi barang yang bermanfaat.

Cara mengelola sampah dapat dengan cara (1) Mengurangi (reduse), sebisa mungkin meminimalisasi barang atau material yang digunakan, karena semakin banyak menggunakan material, semakin banyak pula sampah yang dihasilkan. Mengurangi sampah bisa dilakukan dengan berbagai cara belanja di supermarket dalam jumlah yang besar sekaligus, sehingga akan menghemat jumlah plastik yang digunakan. Bisa juga dengan membawa tas kain saat berbelanja agar tidak perlu lagi menggunakan tas plastik, (2) Menggantikan (replace), mengutamakan penggunaan bahan yang tahan lama merupakan salah satu langkah peminimalisir sampah yang paling efektif. Selain itu, penggunaan bahan yang ramah lingkungan dibanding bahan yang susah terurai akan semakin membantu penanganan masalah sampah. Misalnya, mengganti kantong keresek dengan keranjang bila berbelanja, dan 
menghindari penggunakan styrofoam karena kedua bahan ini tidak bisa terurai secara alami. (3) Menggunakan kembali (reuse), menghindari pemakaian barang-barang yang sekali pakai adalah salah satu cara yang dapat memperpanjang waktu pemakaian barang sebelum ia menjadi sampah (Indiyah dkk, 2020).

Selain itu juga diserahkan rak vertikultur sebanyak 2 unit. Kegiatan perke- nalan dan penyuluhan dilakukan melalui koordinasi PKK RW dan dilakukan di Balai RW agar materi yang disampaikan bisa lebih efektif dan diterima masyarakat dengan baik. Peserta kegiatan ada 20 ibu ibu dengan profil $50 \%$ berusia lebih dari 50 tahunan, $30 \%$ berusia $41-50$ tahun dan $15 \%$ berusia $31-40$ tahun. Dari sisi pekerjaan $17 \%$ diantaranya berwirausaha skala kecil dan $83 \%$ ibu rumah tangga.

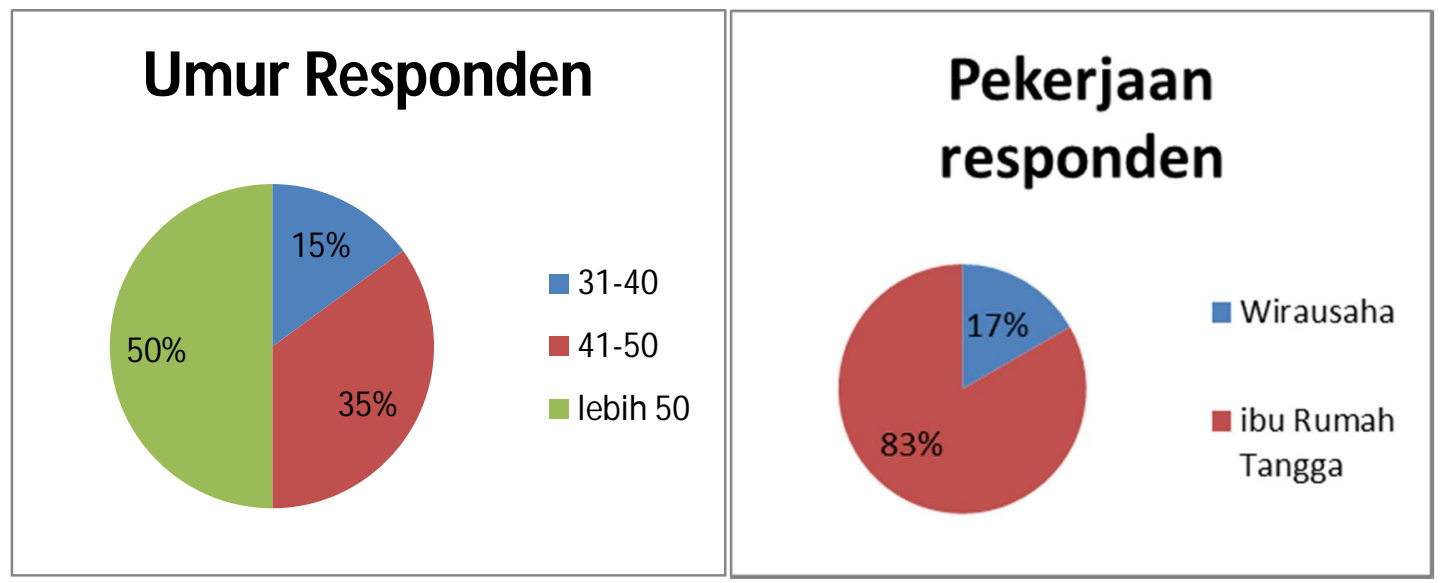

Gambar 2. Profil Peserta Kegiatan

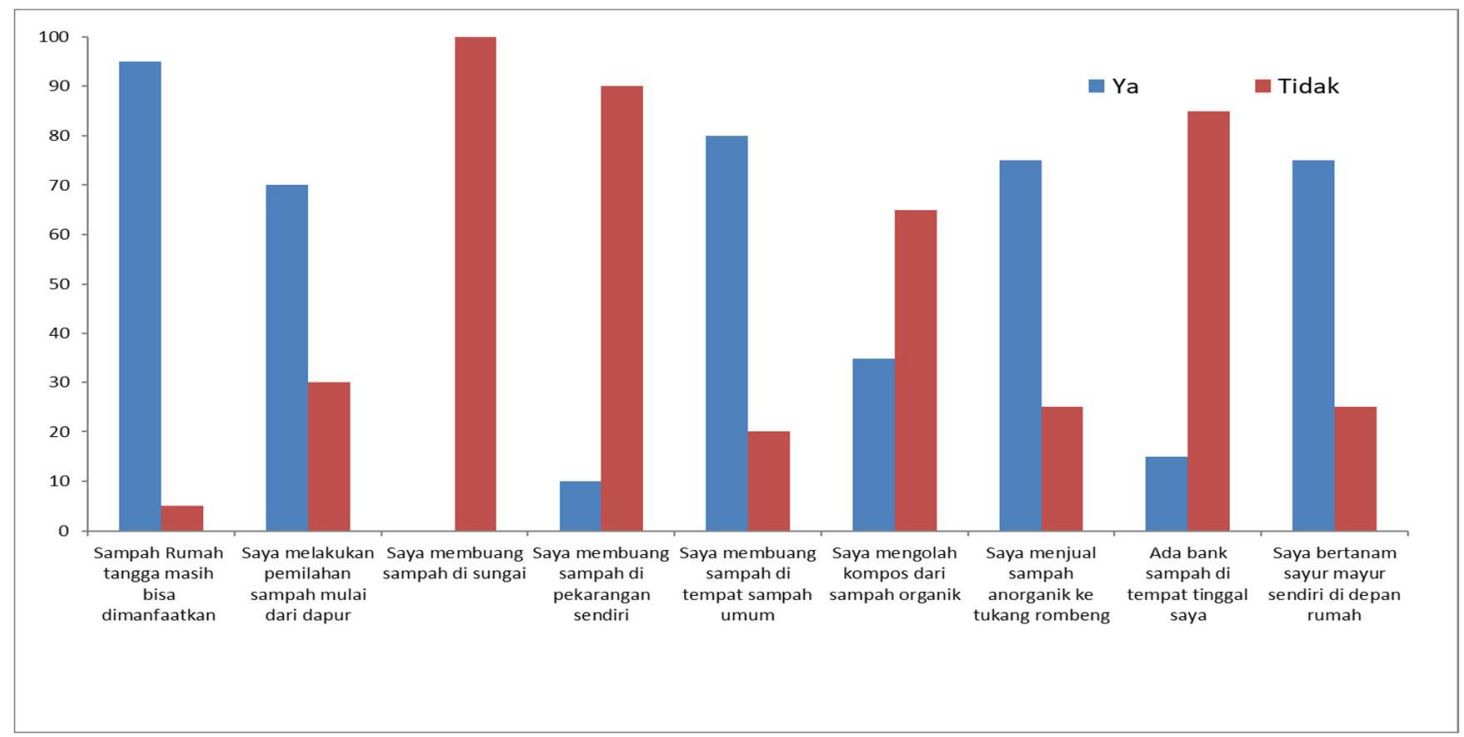

Gambar 3. Grafik pengelolaan Sampah di RW 06 Kel Jatimulyo Malang

Hasil tabulasi data pemahaman para ibu terhadap pemahaman dan kesadaran pengelolaan sampah dan pengetahuan dapat dilihat pada Gambar 3. Dari gambar tersebut dapat dilihat bahwa kesadaran masyarakat untuk tidak membuang sampah di sungai cukup tinggi yaitu sebesar $100 \%$, berarti sudah tidak ada masyarakat yang membuang sampahnya di sungai. Warga yang membuang sampah di pekarangan sendiri juga sangat sedikit yaitu hanya $10 \%$, karena sudah ada petugas sampah yang selalu mengambil sampah, jadi warga membuang sampah pada tempat sampah yang telah ada pada setiap rumah. 

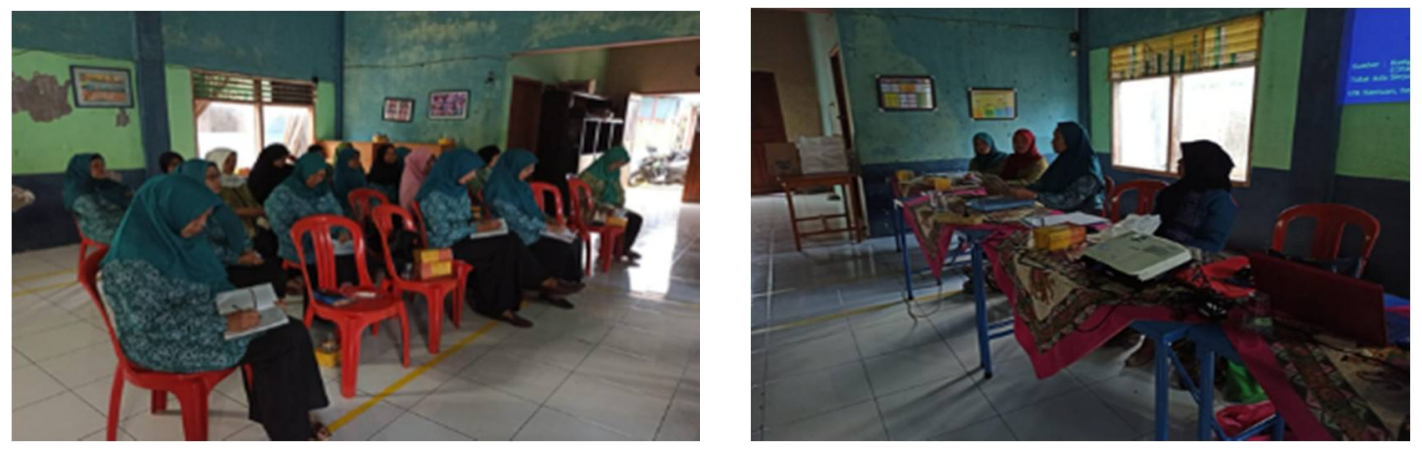

Gambar 4. Kegiatan penyuluhan
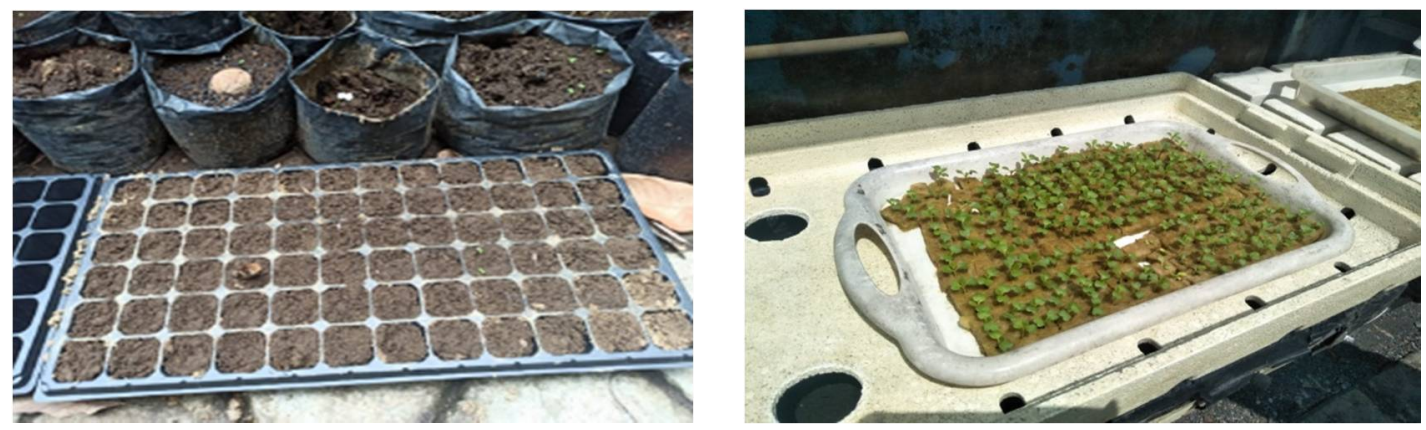

Gambar 5. Pembuatan persemaian
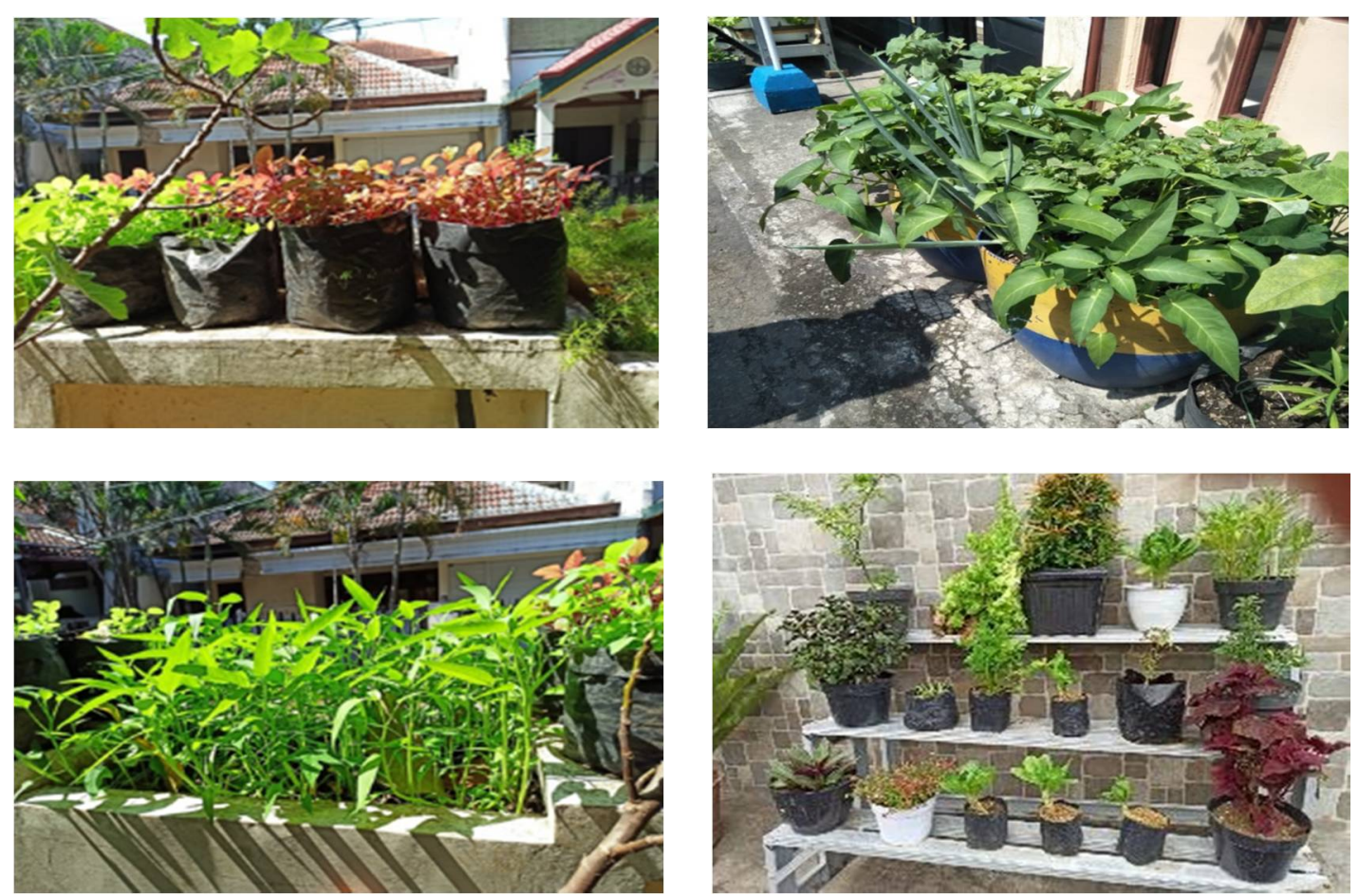

Gambar 6. Pembibitan dan penanaman 
Dari hasil pengamatan di lapang bahwa warga (ibu ibu) sudah melakukan pemi-lahan sampah mulai dari dapur, tapi yang diambil adalah sampah anorganik yang dijual ke tukang rombeng, ibu ibu yang menjual sampah ke tukang rombeng cukup tinggi yaitu sebesar $75 \%$, mereka menjual ke tukang rombeng karena belum optimalnya peranan bank sampah di lingkungannya. Ibu-ibu yang melakukan pemilahan sampah organik dan memanfaatkan sebagai bahan kompos masih cukup rendah, yaitu sebesar $35 \%$. Oleh karena itu tim terfokus melakukan penyuluhan terkait pemanfaatan sampah organik rumah tangga sebagai bahan baku kompos yang dapat dipergunakan sebagai media tumbuh bagi kebun sayur vertikultur.

Kegiatan pengabdian dengan penyuluhan dan pendampingan. Materi utama yang diberikan adalah pemanfaatan sampah organik sebagai kompos dan praktek budidaya sayuran organik yang ditanaman secara vertikultur. Peserta kegiatan cukup antusias menerima materi yang diberikan bahkan menyiapkan areal lahan milik RW untuk bisa dipergunakan sebagai kebun pangan organik. Kegiatan praktek meliputi pembibitan dan penanaman dalam polybag. Polybag dapat diletakkan pada halaman rumah, rak vertikultur atau tempat lain diantaranya seperti pada pagar tembok.

Pembuatan persemaian dengan menebar benih pada tempat persemaian berupa try semai. Media berupa campuran tanah dan pupuk kandang dengan perbandingan 2:1. Media dicampur secara merata dan dimasukkan pada try semai. Benih dimasukkan dalam try semai dan ditutup dengan media yang halus dan disiram secara hati hati, agar benih tidak keluar dari tempatnya. Setelah tumbuh baru dipindahkan ke tempat penanaman berupa polybag.

\section{Simpulan}

\section{Penutup}

Dari hasil pengabdian dapat disimpulkan bahwa kesadaran warga dalam pengelolaan sampah sudah cukup tinggi namun pengetahuan dan keterampilan warga dalam mengelola sampah rumah tangga sebagai bahan baku pupuk organik masih rendah. Kegiatan ini memberikan pemahaman baru bagi warga terkait pengelolaan sampah organik sebagai kompos dan pemanfaatannya untuk media tumbuh kebun vertikultur yang bisa meningkatkan akses keluarga terhadap pangan yang sehat dan bergizi.

\section{Saran}

Dari hasil kegiatan dapat disarankan bahwa masih perlu keberlanjutan program berupa pendampingan dalam pengelolaan sampah rumah tangga, karena masih belum semua menggunakan sampah rumah tangga untuk dijadikan kompos. Pendampingan perlu waktu yang agak lama sehingga proses pembuatan kompos dari awal, mulai dari dapur sampai menjadi kompos yang matang bisa lebih dipahami dan dilanjutkan dengan budidaya tanaman sayur dengan menggunakan kompos yang dibuat oleh warga.

Pertanian berkelanjutan juga perlu diambil sebagai kebijakan pendukung pembangunan yang berbasis perkotaan dan pertanian. Melalui pembangunan pertanian yang inklusif akan dapat terbentuk kelembagaan dan kemitraan ekonomi yang kuat di tingkat perkotaan.

\section{Daftar Pustaka}

Abdalla, I. F. (2012). Socioeconomic aspects of urban and peri-urban agriculture: A diagnostic study in Khartoum, Sudan. kassel university press $\mathrm{GmbH}$.

Alex, S.2016. Sayuran dalam Pot. Sayuran Konsumsi Tak Harus Beli. Pustaka Baru Press. Yogyakarta

BPS, 2010. Produksi Tanaman Sayuran dan Buah-buahan, di Indonesia. Badan Pusat Statistik. Jakarta.

Indiyah M, Asmaniyah, Muslikah dan Anita. 2019. Urban Farming Daerah 
Aliran Sungai. LPPM Unisma. Malang

Untung, K. (1997). Peranan pertanian organik dalam pembangunan yang berwawasan lingkungan. Makalah Yang Dibawakan Dalam Seminar Nasional Pertanian Organik.

Nisa, K. (2016). Memproduksi Kompos dan Mikro Organisme Lokal (Mol). Bibit Publisher.

Liferdi, L., \& Saparinto, C. (2016). Vertikultur Tanaman Sayur. Penebar Swadaya Grup.

Munthe, K., Pane, E., \& Panggabean, E. L. (2018). Budidaya Tanaman Sawi (Brassica juncea L.) Pada Media Tanam Yang Berbeda Secara Vertikultur. Agrotekma: Jurnal Agroteknologi Dan Ilmu Pertanian, 2(2), 138-151.

Noverita, 2005. Pengaruh Konsentrasi Pupuk Pelengkap Cair Nipkaplus dan Jarak Tanam Terhadap Pertumbuhan dan Produksi Tanaman Baby Kaylan (Brassica oleraceae L.) secara vertikultur. Jurnal Penelitian Bidang Ilmu Pertanian, 3(1): 21-29.

Puriandi, F., \& Indrajati, P. N. (2013). Proses perencanaan kegiatan pertanian kota yang dilakukan oleh komunitas berkebun di Kota Bandung sebagai masukan pengembangan pertanian kota di kawasan perkotaan. Jurnal Perencanaan Wilayah Dan Kota,(24), 3, 227-240.

Rosy N, 2017. 30 Teknik Tabulampot Banjir Buah. PT Trubus Swadaya. Jakarta.

Santoso, E. B., \& Widya, R. R. (2014). Gerakan pertanian perkotaan dalam mendukung kemandirian masyarakat di kota Surabaya. Seminar Nasional Cities. 